\title{
Public space as commodity: social production of the Hong Kong waterfront
}

\author{
Elton Chan BArch, MSC \\ PhD candidate, Department of Sociology, Lund University, Lund, Sweden \\ (elton.chan@soc.lu.se) (Orcid:0000-0002-2176-2579)
}

Although there has been a long tradition of public space-related land speculation and development, the recent success of the High Line in New York has highlighted the transformative effect carefully designed and curated public spaces can have on the local economy. By prioritising exchange value over use value, governments and developers are exploiting the production of public spaces as a means for financial, political and other forms of returns. This paper argues that commodification of public space both transcends and encompasses other processes such as privatisation and commercialisation, and it is essential to study how it is manifested in different urban contexts. This paper sets out to examine how commodification of public space has taken form in Hong Kong, a global city where public spaces have mostly been an afterthought and box-checking exercise in the planning process. By reflecting on the social production of three recently completed waterfront public spaces across the city, this paper suggests that even though the commodification of public space has taken on very different forms in Hong Kong, the public spaces in question all display certain characteristics and features that can be attributed to the decline of publicness and inclusivity in public space.

\section{Introduction}

Public spaces such as parks, plazas and squares are traditionally characterised by their universal access and public ownership. Not only are they arenas where people can meet and socialise freely, public spaces have also been contested sites of protests and political expressions. Recent debates surrounding public spaces are mostly centred on privatisation, commercialisation and securitisation and how these contested processes have transformed various public space practices including its design, development and management (Bodnar, 2015). However, although such issues remain highly important, it could be argued that they may no longer suffice to encapsulate the exploitative practices and motives of public space production due to the increasingly complex and dynamic modes of funding, ownership and management in contemporary public space developments. In order to fully understand contemporary public space practices, this paper calls for a different research agenda that encompasses and transcends such existing lines of enquiry. By drawing attention to the domination of exchange value over use value in public space developments, commodification of public space represents a more holistic approach that illustrates how neoliberal and market ideals are spatially and socially encoded in contemporary public space practices. Such an integrated approach requires a closer look at the social production of public space in different political, social and economic contexts. While privatisation, commercialisation and securitisation are mostly centred on the ownership and management of public space, this paper contends that commodification of public space will go beyond such enquiries by providing the necessary framework to pose and answer the question 'what is public space for?'

As Logan and Molotch (2007) argue, cities around the world have become growth machines for profit maximisation and economic boosterism under the proliferation of neoliberal capitalism. Despite traditionally considered as an auxiliary player in the growth machine (Logan and Molotch, 2007), public spaces have recently taken on an increasingly central role in various urban development projects and are thus more likely to be dominated by market logic and exchange value. As a result of the government's heavy involvement in urban regeneration and shortage of land, public spaces in Hong Kong are particularly susceptible to commodification. Drawing on the case studies of three waterfront public spaces in Hong Kong, this paper aims to illustrate how commodification of public space has taken different forms and contributed to the deterioration of public space. This paper will first outline the concept of commodification of public space by critically examining existing debates on public space and critical urban theory, and argue how it can be useful in helping us understand better the linkages between the political economy and public space developments. It will then seek to situate the case studies by outlining the social, political and economic context of Hong Kong, the overview of public space development in the city and the methods used in the empirical research. This is followed by an in-depth examination of the social production of three waterfront public spaces - the Landscape Deck at Kerry Hotel, Tsim Sha Tsui (TST) waterfront and the Kwun Tong Promenade. Finally, the paper will conclude by analysing the findings and suggesting how 
commodification of public space can be a critical and productive tool in future public space studies.

\section{Commodification of public space}

In pure Marxian terms, commodification refers to the transformation of any goods, services and entities into a commodity through the proliferation of market, economic and exchange value, and the subordination of use value (Marx, 1977). Similar to everything else in a capitalist economy, cities and the built environment have also become commodities as a result of the domination of exchange value in the production of urban space (Lefebvre, 1996; Smith, 1979). Even though the entirety of urban life is dictated by capitalist logic and rationale (Lefebvre, 1991), commodification of the built environment has taken on very different forms across the urban fabric. Traditionally, commodification in the city is associated with the financial return of investment in properties and the realisation of increments in rental value (Harvey, 1975; Logan and Molotch, 2007; Smith, 1979). Although public space developments can often have a boosting effect on the surrounding land and property values (Logan and Molotch, 2007), public space is, by definition, neither a tradeable asset in the realestate market nor has any substantial rental value. Even in cities where certain parts of public spaces can be rented out, rents are often highly regulated (Mitrasinovic, 2016). In other words, public space cannot - in principle - function as a profitable investment or a fix for capital accumulation in the same way a luxury apartment can. The commodification of public space is, therefore, a distinct process that is worth studying in its own right.

Commodification of public space illustrates how public space is being produced and developed as a commodity by state and private interests regardless of its ownership, funding and management structure. The exchange value of public space takes on various forms and can be realised in a number of different ways. Most notably, privately owned public spaces (POPS) are increasingly produced by private developers in exchange for zoning exemptions, additional floor areas or other financial incentives through various incentive zoning schemes (Smithsimon, 2008). Commodification of public space can also be driven by indirect financial gains through the increase in land value and tax revenue from nearby properties, city branding, planning and development motives or political goals such as cities cementing their standing within the region, politicians maintaining their personal legacies or corporations leveraging for power and influence on urban development. Regardless of who the stakeholders and what their ulterior motives are, the essence of commodification of public space is the prioritisation of exchange value over use value in the production and distribution of public space. In other words, public space is commodified when its production and development has become primarily a means for the different stakeholders to achieve their own objectives, rather than an end that serves to provide a wellfunctioning public space for the universal public.

According to Logan and Molotch (2007), it is inherently irrational and contradictory for capitalist interests to pursue both exchange values and use values in the city. Similarly, the domination of exchange value in public space production and development tends to come at the expense of use values for the general public, and has thus resulted in a wide array of negative impacts such as the decline in accessibility, inclusivity and publicness (Bodnar, 2015; Loughran, 2014). More crucially, commodification of public space tends to reproduce spatial injustice and exacerbate unequal distribution of resources not only within cities and neighbourhoods, but also across countries and regions. Resources, funding and investments are concentrated on public space developments that are considered to have high exchange value and beneficial to the different stakeholders, while the needs of the public in other areas are often neglected (Loughran, 2014). Moreover, public space developments are also increasingly linked to urban regeneration and gentrification (Lang and Rothenberg, 2016; Rigolon and Neméth, 2018) - the transformative effect carefully designed and curated public spaces can have on the local economy is exemplified by the success of the High Line, the widely celebrated linear park built on a disused elevated railway line in New York City. Consequently, governments and developers around the world are now seeking to emulate the High Line by developing new public spaces as drivers for economic growth and urban development (Lang and Rothenberg, 2016; Loughran, 2014).

\section{Public space developments in Hong Kong}

It could be argued that commodification of public space is particularly prominent in cities such as Hong Kong, where various government agencies have taken an increasingly proactive and central role in its urban planning and development. As the largest land-owner of the city, the government relies heavily on urban (re)development to generate profit - land premium in Hong Kong constitutes by far the largest portion of the state capital revenue (LCS, 2018). By managing land supply and devising the statutory plans, the government can dictate the pace and form of urban development in Hong Kong largely based on market forces (La Grange and Pretorius, 2016; Ng, 2002), often without any meaningful public consultation or substantial resistance. Furthermore, as La Grange and Pretorius (2016) argue, urban regeneration in Hong Kong is a distinct process that is shaped by its unique urban morphology, political institutions and socio-economic structures. Unlike most Western cities, gentrification in Hong Kong is often stimulated by the government as a consequence of state-driven urban redevelopment projects (La Grange and Pretorius, 2016). As much of the inner city continues to be penetrated by state-led gentrification, public space 
provision in Hong Kong has become increasingly predominated by exchange value and market logic.

Even though the need for public space provision is formally recognised by the government in its planning regulations and guidelines (PlanD, 2018), the socio-spatial quality and design standard of the public space are neither clearly defined nor regulated (Lai, 2017; Lam et al., 2005). In other words, the planning and design of public spaces in Hong Kong are largely centred on quantitative measurements such as the size of the public spaces rather than qualitative characteristics that shape how they are utilised by the public or how they can better facilitate social interactions (HKPSI, 2018a). The development of public space in Hong Kong has, therefore, often become an afterthought and a box-checking exercise in the planning process. Moreover, due to the increasing density and pace of urban development, the demand for public space in Hong Kong has skyrocketed in recent years. Coupled with the shortage of land in the inner city, the government has struggled to provide enough public space for the growing urban population (Tang, 2017). As a result, the responsibility for local public space provision has gradually fallen into the hands of private developers - POPS developed through various incentive zoning schemes have become an increasingly commonplace across the city centre (Cuthbert, 1995; Cuthbert and McKinnell, 1997; Tang and Tang, 1999). Meanwhile, the government has also assumed a more prominent role in large-scale public space developments, where the transformative effect of public space is the most apparent. Flagship public space projects such as city parks and waterfront promenades are often key components in the government's plans for urban (re)developments. In fact, it could be argued that such public spaces are increasingly developed as vehicles for driving urban redevelopment and stimulating state-led gentrification.

It is against this background that this paper seeks to illustrate how exchange value and market logic have taken over public space practices in Hong Kong and to outline the variegated forms of public space commodification by examining the social production and development of different public spaces in Hong Kong. This paper will analyse three recently completed or renovated public spaces that are located in different neighbourhoods along the waterfront of the largely urban Kowloon Peninsula (Figure 1). In addition to the relative spatial and temporal proximity, the public spaces included in this study are chosen based on three main reasons. First of all, they are all located along the waterfront, which is a highly contested site in Hong Kong due to its real-estate value and symbolic significance. The development of waterfront promenades and public spaces plays a particularly crucial role in assuring public access to the harbour. Second, even though the public spaces are located in areas with very different socio-economic structures, they are all situated in mixed-use neighbourhoods where various stakeholders have conflicting opinions and have thus been subjects of public debate. Most importantly, despite their spatial and temporal proximity, the three public spaces have very different funding, ownership and operation models. They are, therefore, representative of not only the diverging trends of public space development in Hong Kong, but also the variegated nature of public space commodification.

\section{Approach and methods}

The focus of this study is centred on the social production of public space, which as Low suggests, 'illuminates how a space or place comes into existence and opens up questions about the political, economic and historical motives of its planning and development' (Low, 2017: p. 34). The interdisciplinary approach of conceptualising the social production of public space requires 'a layered set of methodologies that crosscut time and space' (Low, 2017: p. 48) and forms the point of departure for this investigation on the commodification of public space in Hong Kong. The majority of data collection is performed by reviewing and analysing planning and policy documents, Legislative Council and District Council meeting minutes, local and international media reports, promotional and marketing materials from developers and governmental offices as well as censuses and other socio-economic indicators. Such data provide not only an overview of public space developments in Hong Kong, but also particular insights into the funding, planning, design and operation of the three public spaces in question. In addition to review and analysis of documents, two rounds of fieldwork were undertaken over a 4-year span. Initial socio-spatial analysis was based on participant observations conducted in 12 different public spaces between 2016 and 2017 as a preliminary study on public space practices in Hong Kong. Among the 12 public spaces, three waterfront public spaces were identified and selected as case studies for the investigation on commodification of public space.

In order to further examine the social production of the Hong Kong waterfront and how commodification of public space takes form differently among the three cases, more in-depth investigation was undertaken to establish, among other things, who the different user groups consist of, how they move and behave in the public spaces and what their opinions of the public spaces are. Additional fieldwork, which entails behavioural observations in the public spaces and their surrounding neighbourhoods, as well as informal conversations with local residents and other public space users, was thus carried out from 2018 to 2019. At least five separate site visits, which lasted between 1 and $4 \mathrm{~h}$, were conducted in each of the three public spaces to capture the wide variety of behaviours of different public space users. In addition to the behavioural observations, multiple informal conversations were held with various people including public space users, security guards and maintenance staff in each public space during the site 


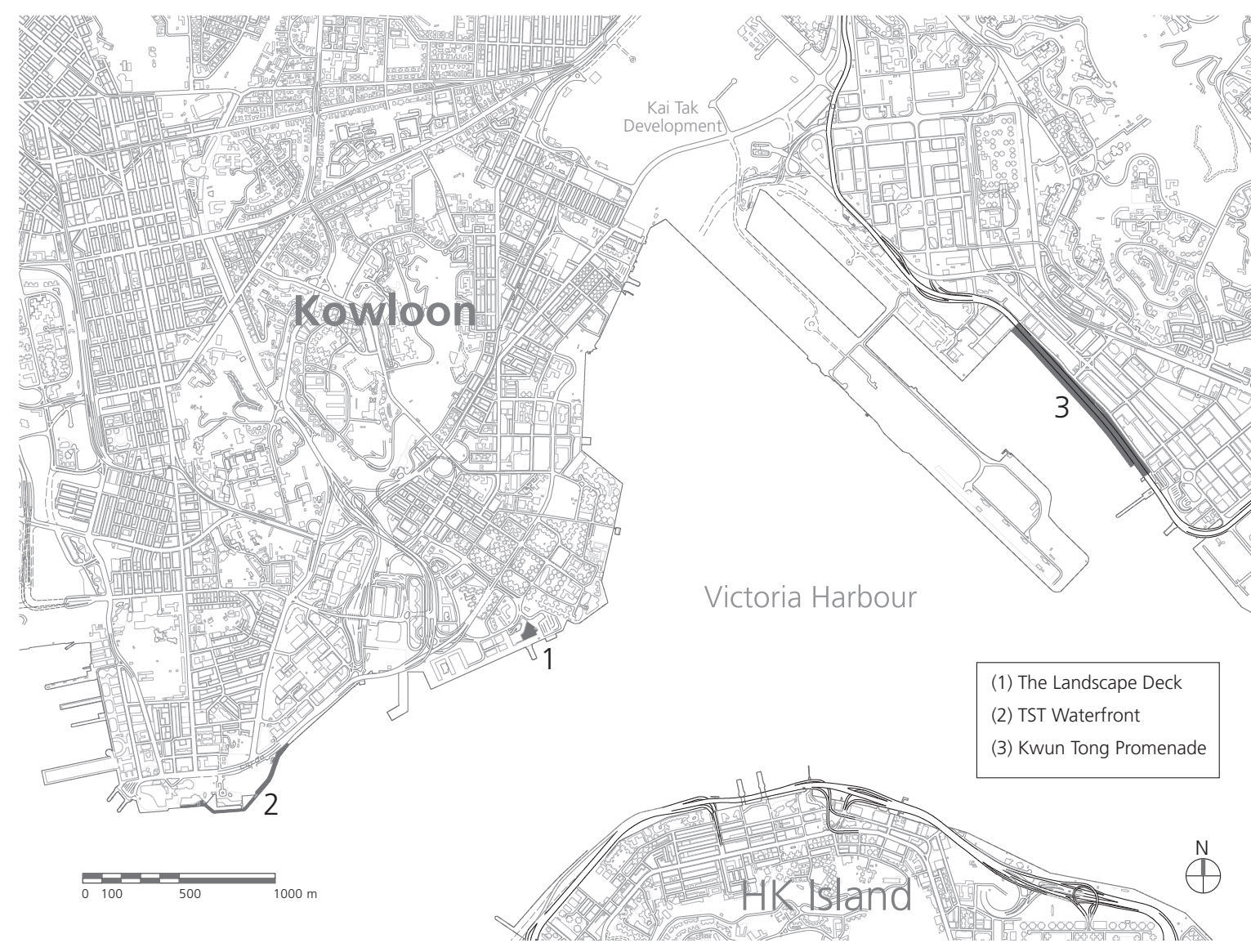

Figure 1. Location map: (1) the Landscape Deck at Kerry Hotel, (2) TST waterfront, (3) Kwun Tong Promenade

visits. Instead of gaining detailed knowledge of specific actors and stakeholders, these conversations intend to complement the behavioural observations by providing a broad contextual background and a general overview of the public space users. Moreover, semi-structured interviews with architects, government planners, developers, politicians and community representatives were conducted to substantiate the points of view of the key actors and stakeholders in the social production of the three waterfront public spaces. The documents, field notes and interview transcripts are coded and analysed using a qualitative descriptive approach, and the findings are incorporated in the following discussions of the three case studies.

\section{Results and findings}

\subsection{The Landscape Deck at Kerry Hotel}

The Kerry Hotel is a luxury hotel opened in 2017. It is located on the waterfront in Hung Hom, a residential neighbourhood by the harbour (Figure 1). On the podium of the hotel complex is a public space called the Landscape Deck that can be accessed from both the hotel lobby and the waterfront promenade. The public space consists of two levels of landscaped open space and an outdoor seating area for a restaurant. The Landscape Deck, which is owned and managed by the hotel, is designated for public use as part of the conditions of the planning permission (TPB, 2013). It is an archetypal POPS that has become increasingly widespread across Hong Kong. Similar to the incentive zoning and planning provision schemes in other cities around the world, private developers in Hong Kong are rewarded with additional developable floor space for providing public space and other public amenities as part of their developments (Tang and Tang, 1999). POPS in Hong Kong can be found in not only commercial and retail projects, but also as part of residential and office developments. Even though the public access of POPS is technically guaranteed in the land lease, the deeds of dedication or as part of the planning requirements, the terms are often vague and unclear, and there is a general lack of oversight once the public space is in operation. Developers and building managements are seldom punished for bending the rules or not adhering to the agreed terms and conditions. For instance, there have been many cases in Hong Kong where POPS, especially those connected to 
shopping malls, are used for unauthorised commercial activities by private developers or building management companies (HKPSI, 2018a). As a result, POPS in Hong Kong are often less accessible and inclusive compared with other public spaces.

On paper, the Landscape Deck at Kerry Hotel can be a useful addition to the waterfront as it provides the users with an elevated viewpoint and a different experience of the harbour, as well as a green open space that contrasts the linear promenade. However, although it is generally a well-designed space, the Landscape Deck is problematic in a number of ways. First of all, the Landscape Deck can only be accessed, from the waterfront, through an inconspicuous entrance and staircase (Figure 2). The signage that indicates the public accessibility of the Landscape Deck is not only located well below eye-level, but it is also partially blocked by a large planter, making it difficult for people walking along the promenade to notice the existence of the public space. As stated in a recent report published by Hong Kong Public Space Initiative, one of the most common problems regarding accessibility of POPS in Hong Kong is the lack of signage (HKPSI, 2018a), and the Landscape Deck is a good case in point. Second, the hotel management has imposed strict restrictions on the types of activities that can be carried out on the Landscape Deck. The prohibited activities include 'loitering', 'gathering' and 'consuming outside food', and it is clearly stated on one of the signs that 'the hotel reserves the right to deny access from anyone who fails to comply with such rules'. The lack of furniture and shaded area makes it difficult for people to spend a substantial amount of time on the Landscape Deck. In fact, the only shaded section of the Landscape Deck was cordoned off and demarcated as an outdoor seating area for one of the hotel restaurants (Figure 3). Finally, despite being a public space, the Landscape Deck is actually inaccessible to the public most of the time - it is only open daily from 10.00 a.m. to 9.30 p.m., which is shorter than the $13 \mathrm{~h}$ recommended by the government (DevB, 2011). The late opening time also means that people will not be able to do their morning exercises on the Landscape Deck, a popular habit among the elderly. Furthermore, there have been many instances when the entire Landscape Deck was closed off for private functions or 'maintenance purposes' during the first few months of its opening (Cheung, 2017).

Despite the architect's attempts to activate the public space through its design, it is clear that the hotel management has attempted to discourage public use in the Landscape Deck by limiting its accessibility, inclusivity and publicness. This is exemplified by the placement of large planters along the section of the main staircase that was originally designed as a public seating area (Figure 3). The result is a bland, underused and sterile space that is easy to manage and causes minimal intrusion to the privacy of the paying hotel guests. As Smithsimon (2008) concludes in his study of bonus plazas in New York, these POPS are often empty not due to it is too expensive or complicated to make them useful, it is rather the objective of the developers to create a highly exclusive public space - exclusion is, in many ways, 'a goal of its own' (Smithsimon, 2008: p. 335). It could be argued that the widely adopted incentive zoning scheme has led to the deterioration of public space in Hong Kong by exacerbating the box-checking nature of public space provision. Privatisation, in this case, is also a form of commodification - public space provision has become a commodity and is dictated by exchange value.
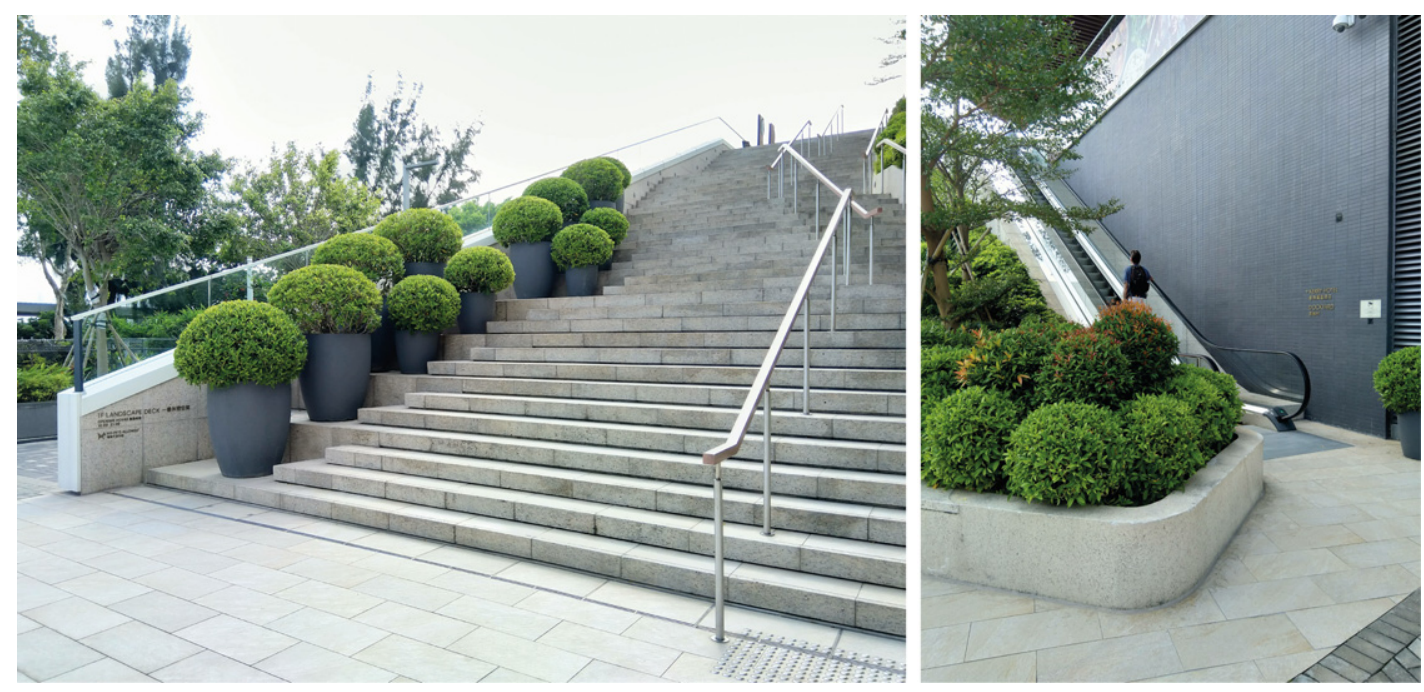

Figure 2. Entrance to the Landscape Deck at Kerry Hotel 

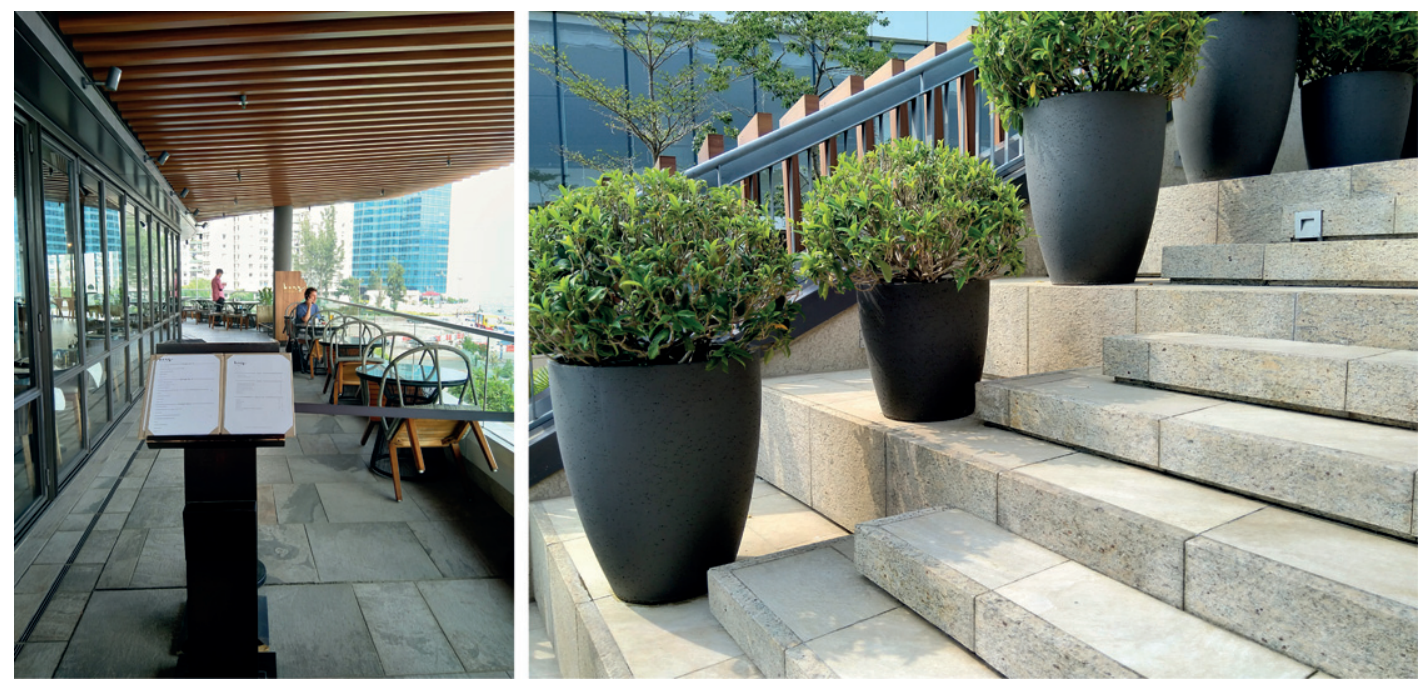

Figure 3. Seating arrangements on the Landscape Deck

The sole purpose of including a public space within the hotel is for the developer and management to maximise their profit in their development. Not only is providing a vibrant and dynamic public space not beneficial to the private interests producing them, but it can often have a negative impact on their property values. It is this inherent tension between the publicness that is desired in a public space and the exclusivity often demanded by the developers that makes POPS particularly problematic in contemporary urban development.

\subsection{Tsim Sha Tsui waterfront}

The TST waterfront promenade is a public space and tourist attraction in the heart of the city (Figure 1). The promenade, which is one of the landmarks of Hong Kong, offers visitors a great view of the iconic Hong Kong Island skyline, the harbour and the Victoria peak. It is also within the walking distance to a number of cultural institutions and tourist attractions such as the Cultural Centre, the Museum of Art and the Space Museum (Figure 4). Although the promenade is often full of tourists, street vendors and hawkers, many local residents tend to stay away from the waterfront, which is considered to be one of 'the world's worst tourist trap', leading to calls for improvement works on the promenade (GovHK, 2011). The TST Waterfront Revitalisation Plan was first proposed by the government and a private developer in 2013 . Even though public-private partnerships are not uncommon in Hong Kong, the plan was especially controversial due to the significance and complexity of the proposal.

By adopting a Partnership Approach instead of the traditional public-private partnership model, the government decided to give the development and operation rights of the waterfront to
New World Development (NWD), a private developer who owns the adjacent Victoria Dockside hotel and commercial complex, without an open tender process or proper public consultations (GovHK, 2015). Under the Partnership Approach, the government would maintain sole ownership and ultimate management right of the site, while the revitalisation of the site is funded and carried out by NWD. More crucially, however, the daily operation of the site would be formally undertaken by a non-profit organisation that was set up by NWD. When questioned about the legitimacy and legality of such an arrangement, the then Secretary for Home Affairs argued that since the project is neither for profit nor commercial in nature, it is not obliged to follow the government guidelines that requires any public-private partnership proposals to be tendered out for open bidding (GovHK, 2015). The arrangement raised concerns and suspicions of collusions among politicians, businesses and the Hong Kong public (Fung and Lai, 2015). Amidst further public pushbacks and potential legal battles, NWD ultimately decided not to assume management of the entire waterfront promenade.

However, NWD is still contracted to operate the Avenue of Stars (Figure 4) - the section of the TST waterfront promenade outside its Victoria Dockside development - and the developer has proceeded with its revitalisation. James Corner Field Operations, the firm who designed the High Line in New York, was hired as the lead designer. The revamped Avenue of Stars exemplifies the widespread impact of the 'High Line Effect' that does not only characterise the transformative effect of the High Line, but also encapsulates the circulation and universalisation of the concept, design and execution of the project (Lang and Rothenberg, 2016). 

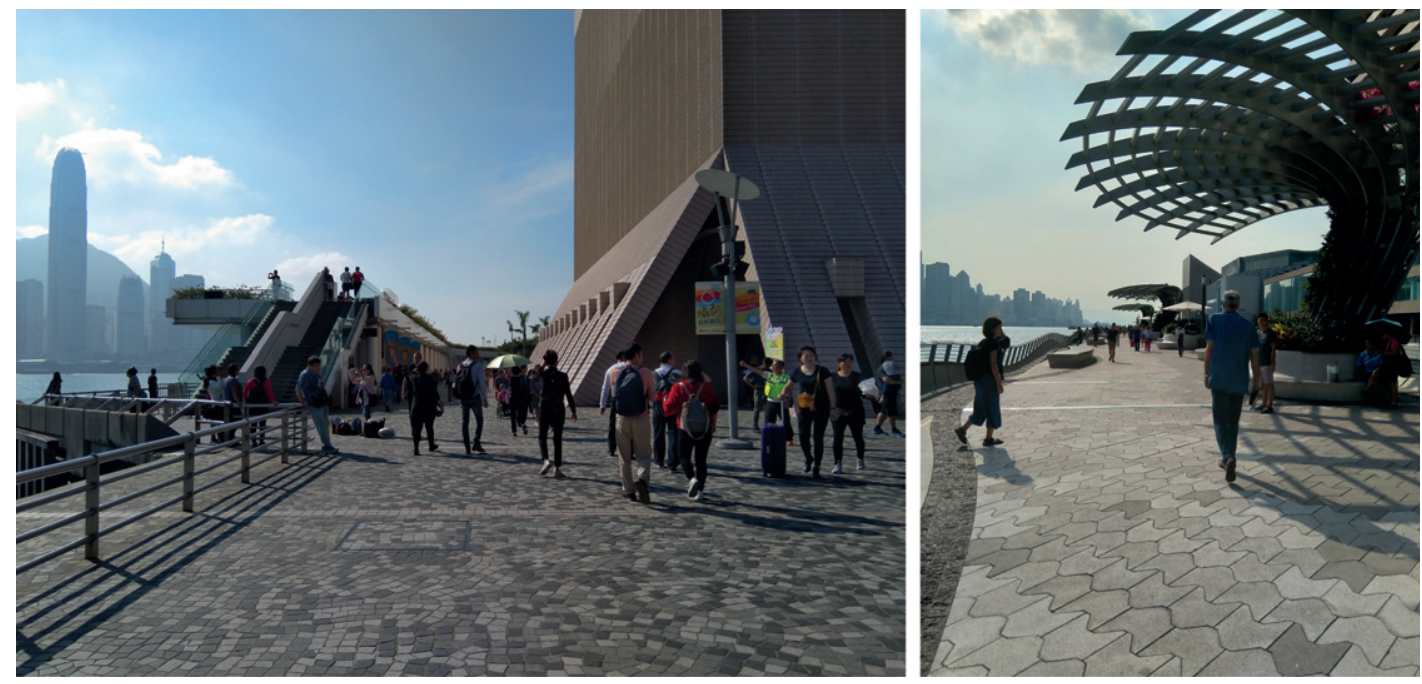

Figure 4. TST waterfront: area outside the Cultural Centre (left) and the newly renovated Avenue of Stars (right)

The High Line, in spite of its design merits and success as a tourist attraction, is a commodified public space that lacks inclusivity and publicness. As Reichl illustrates, the High Line is a segregated space that 'render[s] marginalised groups and their experiences invisible' (Reichl, 2016: p. 922). Similarly, it appears that the revamped Avenue of Stars has been transformed into a carefully designed and highly curated public space that seeks to attract visitors that fits the ideal client profile for Victoria Dockside, which is marketed as the 'New Cultural Frontier of Hong Kong' (NWD, 2018). As a representative of the developer stresses in an interview, 'commercial developments and public spaces are often complementary to each other' and it is in his opinion that the success of the Avenue of Stars as a tourist attraction is largely beneficial to the businesses of the entire development.

Despite not being realised, the TST Waterfront Revitalisation Plan, along with the renovation of Avenue of Stars, illustrates how market logic has penetrated public space practices in Hong Kong. It is also an indication of how future public space development can take form and a prime example of how government and its private partners utilise innovative funding and management models in public space development for financial and political gains. As Bodnar argues, 'the triad of private management, public ownership and public access has become the new recipe and norm for public space regeneration' (Bodnar, 2015: p. 2096). Even though governments and private developers may be driven by different motivations, they often share the same goal in creating a spectacle that attracts tourism and investment. To the government, the revitalisation of the TST waterfront is a city-branding exercise that seeks to strengthen Hong Kong's position as 'Asia's World City'.
In contrast, the developer sees the overhauled Avenue of Stars as an investment that will pay itself off by drawing people to its nearby shopping mall and hotel. Although such a management model in public space developments may be mutually beneficial to the government and its private partners, this paper maintains that such public-private partnerships are often established at the expense of public interests by disregarding the needs of the local community.

\subsection{Kwun Tong Promenade}

Kwun Tong is a former industrial district that has been one of the poorest districts in Hong Kong. Since the turn of the century, Kwun Tong has undergone substantial physical and socio-economic changes. Industrial buildings are being torn down and redeveloped into new offices and shopping centres as part of the government's district-wide revitalisation plan that seeks to transform Kwun Tong into a second central business district. Many of the old residential buildings and housing estates in Kwun Tong are also gradually being replaced by new luxurious apartment blocks. The influx of new higher-income residents - together with the ageing population of the local area - has led to a growing demand for public spaces and recreational facilities in the district. One major addition to the district's limited public spaces is the Kwun Tong Promenade (the Promenade) (Figure 1), a kilometre-long park by the Kwun Tong Typhoon Shelter that features facilities such as children's playgrounds, a viewing deck, seaside boardwalk, a multi-purpose event space and some grass lawns with a variety of trees, plants and shrubs (Figure 5). Unlike the Landscape Deck at Kerry Hotel and the TST Waterfront Revitalisation Plan, the Kwun Tong Promenade is publicly funded, designed and operated. 
The Promenade, which was first opened in 2010, is also the first open space of the Kai Tak Development - a large-scale redevelopment of the nearby old Kai Tak Airport that includes a multi-purpose sports complex, a Cruise Terminal and a hotel, as well as residential and commercial areas.

Despite winning a number of design awards, the Kwun Tong Promenade is largely underused and unpopular among local residents (HKPSI, 2018b). One of the main reasons is that the Promenade is located far away from the residential area of Kwun Tong, making it particularly difficult for any elderly people or children to visit. Moreover, the Promenade also lacks facilities that are more suited to the needs of the local elderly population such as chess tables and senior exercise equipment. In contrast, it is a popular destination among youths and young families from all over Hong Kong, who go there for dates and social outings in the weekends (HKPSI, 2018b). The fact that the Kwun Tong Promenade is one of the few parks in Hong Kong that has its own dedicated parking spaces for cars and coaches (Figure 5) exemplifies both its relative inaccessibility to the public and orientation towards visitors from outside of Kwun Tong. The recent trial run of turning a section of the Promenade into a shared space for both cyclists and pedestrians is another case in point of how the waterfront public space does not cater to the needs of the local community. Cycling in Hong Kong is a leisure activity that is traditionally enjoyed by the upper-middle class, who can afford not only the bicycles, but also the space and means to store and transport them. According to the Travel Characteristics Survey published in 2014, only $10 \%$ of households in Hong Kong have bicycles available for use (TD, 2014). It could, therefore, be argued that the implementation of shared space on the Promenade is further evidence of the inclination towards affluent visitors from outside of Kwun Tong instead of the local residents.

In addition, the government-controlled Legislative Council has, despite strong local opposition, recently approved a proposal to build a $100 \mathrm{~m}^{2}$ musical fountain in the middle of Kwun Tong Promenade (Cheng, 2018). The musical fountain, which was first proposed in 2014 as part of the Signature Project Scheme - a one-off government grant for each district to carry out a 'signature project', will cost 6.5 million USD $(1 \mathrm{HKD}=0.13 \mathrm{USD})$ of the taxpayer's money. Supporters of the project argue that the musical fountain will draw tourists and visitors to the area and, therefore, stimulate the local economy. However, many local residents believe not only will it not bring anything to the waterfront, but the musical fountain will also take up a large section of open space that can be instead used for jogging or yoga. Others also fear that the new tourist attraction will put immense pressure on road traffic, public transport and other infrastructure. More importantly, the proposal also heightens the unequal distribution of resources and spatial injustice within a largely poverty-stricken district, where many local public services and facilities are in dire need for improvement. For instance, it is not uncommon for elderly residents to bring their own chairs or sit on the floor to play chess due to the lack of functioning benches and tables in their local parks. It could be argued that the decision to build the musical fountain under such circumstances is particularly controversial and emblematic as it exemplifies not only the perpetual neglect of the local community, but also the uneven development that has been taking place within the district in the last decade or so. As multiple local community representatives maintain, instead of spending the money on a
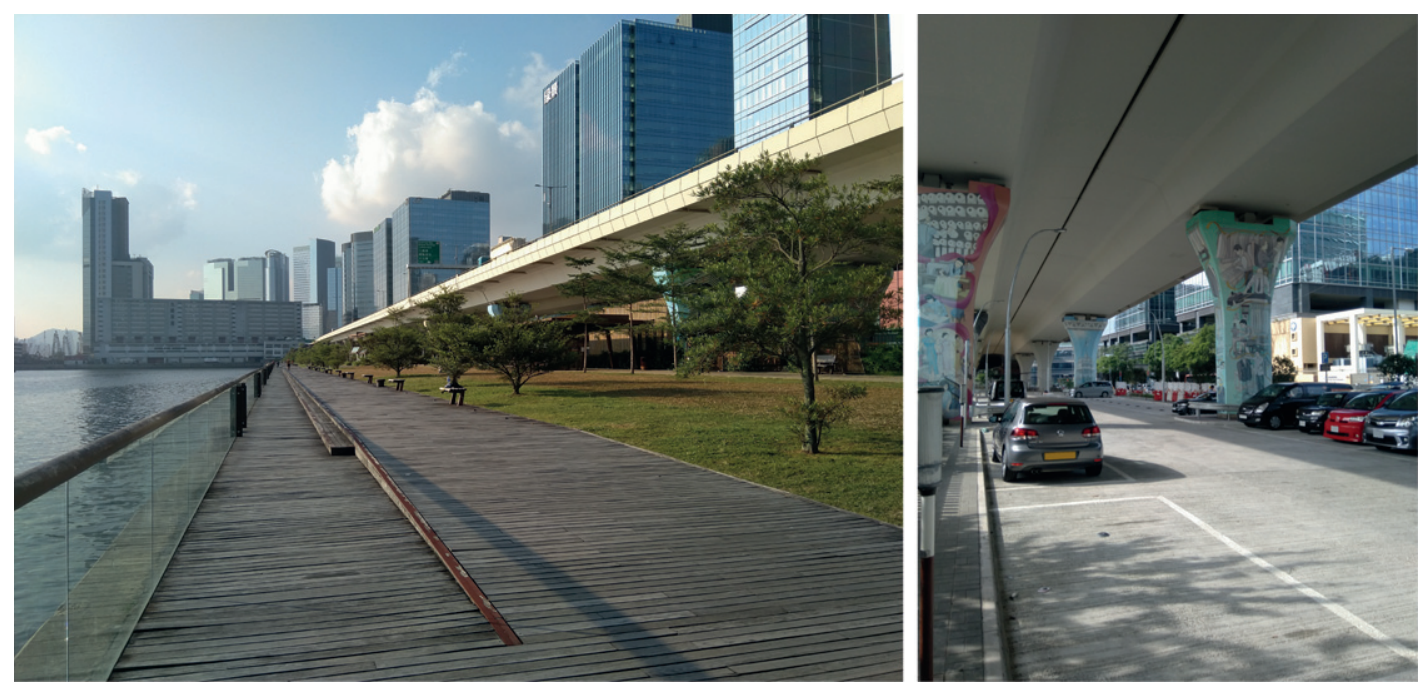

Figure 5. Kwun Tong Promenade (left) and its dedicated car park (right) 
tourist attraction that is rarely used by the local residents, it would be more sensible to invest it on the local community by improving the dated facilities and equipment in local parks or strengthening the eye and dental care programmes for the elderly.

The Kwun Tong Promenade and its 6.5 million USD musical fountain addition is an exemplary case of government-driven commodification of public space. As the largest land owner in Hong Kong and in the nearby Kai Tak Development, it is clear that by transforming the Kwun Tong waterfront into a landmark and tourist attraction, the government seeks to drive up property and land values by attracting tourists and investments to the area. Instead of an inclusive and accessible public space for the local community, the government sees the Kwun Tong Promenade as 'an impetus to the revitalisation of the Kwun Tong industrial area, taking account of the Government's new initiatives in this area' (GovHK, 2010). Although the Promenade may not have itself triggered the urban regeneration in Kwun Tong, this paper argues that the beautification of the waterfront has played an important role in transforming the area and accelerated the state-led gentrification process by enhancing the image of Kwun Tong among Hong Kongers and foreign investors.

\subsection{Discussion}

Although the three waterfront public spaces have very different ownership and management models, they are all representatives of the increasingly neoliberal practices of public space development and the variegated nature of public space commodification. It could be argued that the provision of public space is increasingly being exploited and instrumentalised, especially in areas that are undergoing rapid urban transformations and highly-contested sites such as the waterfront of Hong Kong. Despite fundamental differences in terms of design, planning and operation, the three waterfront public spaces are similarly characterised by the domination of exchange value and market logic. To the government and the private developers, the inherent value of the waterfront has nothing to do with it being an inclusive and accessible public space; the value and success of its development is largely dependent on what they can gain in exchange. In all of the above cases, the development of public space has become a means to achieve financial, political or redevelopment objectives rather than an end for public utilisation and sociability. This is particularly evident in Hong Kong, where public space often plays an important role in the state-led gentrification and urban regeneration that has become increasingly a commonplace across the urban centre. As a result, the opinions and concerns of the residents, especially marginalised groups such as ethnic minority and low-income families, were overlooked in the design and planning processes of the public space developments. As demonstrated in the three waterfront public spaces, the commodification of public space has not only exacerbated the deterioration of public space in Hong Kong, but also heightened spatial injustice within different neighbourhoods. It does not matter whether the waterfront public space projects are driven by financial, political or other motivations, as long as there is an ulterior motive behind its development, the waterfront will never fulfil its potential as a dynamic, inclusive and accessible public space.

\section{Conclusions}

According to Low, 'a social production of space analysis provides insights into the many processes of uneven development and the multiple ways that capitalism destroys and recreates the built environment' (Low, 2017: p. 66). Drawing on the social production of three distinct waterfront public spaces in Hong Kong, it is clear that processes such as privatisation, commercialisation and securitisation alone can no longer comprehend the increasingly complex and exploitative nature of public space developments. As such, this paper maintains that it can be useful and productive to shift the focus of public space research from the existing lines of enquiry to commodification of public space that represents a more holistic and integrated approach that encapsulates the interplay of the different processes transforming contemporary public space practice. However, it must be stressed that the problem with commodification of public space is not the transformative effect of public spaces - a public space should, and will always, be a boost to its immediate surroundings; the problem lies in the exploitative intentions and motivations of contemporary public space developments. Instead of asking by whom and how public spaces are developed and managed, this paper argues that it is more pertinent to question why, as well as at what costs, certain public space projects are being pursued.

It is evident from the cases examined in this paper that regardless of whom the public space is funded, owned or managed by, public space developments are increasingly driven by market logic and exchange value rather than the use value of the public. Although the commodification of public space can take on very different forms depending on its development model, it often results in a similar decline in inclusivity, accessibility and publicness of the public space. In contrast, commodification of public space is also increasingly linked to the uneven development of neighbourhoods, cities and even regions. Heightened spatial injustice and gentrification are some of the socio-spatial consequences of public space commodification highlighted in this paper. More importantly, the findings suggest that private developers are no longer the sole antagonists of the deterioration of public space, as governments and states are increasingly involved in the commodification of public space. Highly curated and regulated 
public spaces that are publicly funded and operated can be just as restrictive and problematic as POPS, and should, therefore, receive the same level of scrutiny and critical attention. By examining the social production of three distinct waterfront public spaces in Hong Kong, this paper has illustrated how commodification of public space can capture both the exploitative motives and the socio-spatial impacts of prioritising exchange value over use value in a wide range of public space developments. As public space developments become increasingly complex, it could be argued that commodification of public space represents a more comprehensive approach that is better suited for future public space investigations in different social, political and economic contexts.

\section{REFERENCES}

Bodnar J (2015) Reclaiming public space. Urban Studies 52(12): 2090-2104.

Cheng K (2018) Divisive HK\$50m 'White Elephant' Musical Fountain Approved by the Hong Kong Legislature. Hong Kong Free Press, Hong Kong.

Cheung K (2017) How Hong Kong's Developers are Abusing Public Space. Hong Kong Free Press, Hong Kong.

Cuthbert AR (1995) The right to the city: surveillance, private interest and the public domain in Hong Kong. Cities (London, England) 12(5): 293-310.

Cuthbert AR and McKinnell KG (1997) Ambiguous space, ambiguous rights - corporate power and social control in Hong Kong. Cities (London, England) 14(5): 295-311.

DevB (Development Bureau) (2011) Public Open Space in Private Developments Design and Management Guidelines. Development Bureau, HKSAR Government, Hong Kong.

Fung FWY and Lai YK (2015) Lights out for Avenue of Stars as Iconic Hong Kong Site Set to Shut Down for Three Years Despite Public Outcry. South China Morning Post, Hong Kong (accessed 21/08/2015).

GovHK (HKSAR Government) (2010) Harbourfront Promenade Opened in Kwun Tong (with Photos). HKSAR Government, Hong Kong. See https://www.info.gov.hk/gia/general/201001/16/P201001160137. htm (accessed 19/08/2020).

GovHK (2011) LCQ4: Tourist Attractions in Hong Kong. HKSAR Government, Hong Kong. See https://www.info.gov.hk/gia/ general/201110/26/P201110260272.htm (accessed 19/08/2020).

GovHK (2015) LCQ4: Tsim Sha Tsui Waterfront Revitalisation Plan. HKSAR Government, Hong Kong. See https://www.info.gov.hk/ gia/general/201511/04/P201511040484.htm (accessed 19/08/2020).

Harvey D (1975) Social Justice and the City. Edward Arnold, London, UK.

HKPSI (Hong Kong Public Space Initiative) (2018a) Privately Owned Public Space Audit Report. Hong Kong Public Space Initiative, Hong Kong. See http://www.hkpsi.org/chi/projects/pops-audit/ (accessed 19/08/2020).

HKPSI (2018b) An urban experiment to explore great public space design. In Space X Hong Kong (Hong Kong Green Building Council (ed.)). Hong Kong Green Building Council Limited, Hong Kong, pp. 66-93.

La Grange A and Pretorius F (2016) State-led gentrification in Hong Kong. Urban Studies 53(3): 506-523.
Lai C (2017) Unopened Space: Mapping Equitable Availability of Open Space in Hong Kong. Civic Exchange, Hong Kong.

Lam KC, Ng SL, Hui WC and Chan PK (2005) Environmental quality of urban parks and open spaces in Hong Kong. Environmental Monitoring and Assessment 111(1-3): 55-73.

Lang S and Rothenberg J (2016) Neoliberal urbanism, public space, and the greening of the growth machine: New York City's High Line park. Environment and Planning A: Economy and Space 49(8): 1743-1761.

LCS (Legislative Council Secretariat) (2018) Major Sources of Government Revenue. Research Office, Legislative Council Secretariat, Hong Kong, ISSF03/17-18.

Lefebvre H (1991) The Production of Space. Blackwell, Oxford, UK. Lefebvre H (1996) Writings on Cities. Blackwell, Oxford, UK. Logan JR and Molotch H (2007) Urban Fortunes: The Political Economy of Place. University of California Press, Berkeley and Los Angeles, CA, USA.

Loughran K (2014) Parks for profit: the high line, growth machines, and the uneven development of urban public spaces. City \& Community 13(1): 49-68.

Low S (2017) Spatializing Culture: The Ethnography of Space and Place. Routledge, New York, NY, USA.

Marx K (1977) Capital: A Critique of Political Economy. Random House, New York, NY, USA.

Mitrasinovic M (2016) Total Landscape, Theme Parks, Public Space. Routledge, New York, NY, USA.

Ng MK (2002) Property-led urban renewal in Hong Kong: any place for the community?. Sustainable Development 10(3): 140-146.

NWD (New World Development) (2018) Victoria Dockside Launches Hong Kong to a New Cultural Frontier Adrian Cheng Creates First Wave of Excitement at the $3 \mathrm{~m}$ Sqft Art and Design District. New World Development Company Limited, Hong Kong. See https://www.nwd.com.hk/content/victoria-dockside-launches-hongkong-new-cultural-frontier-adrian-cheng-creates-first-wave-2 (accessed 19/08/2020).

PlanD (Planning Department) (2018) Chapter 4 Recreation, open space and greening. In Hong Kong Planning Standards and Guidelines. Planning Department, HKSAR Government, Hong Kong, pp. 1-59.

Reichl AJ (2016) The High Line and the ideal of democratic public space. Urban Geography 37(6): 904-925.

Rigolon A and Neméth J (2018) 'We're not in the business of housing:' environmental gentrification and the nonprofitization of green infrastructure projects. Cities (London, England) 81: $71-80$.

Smith N (1979) Toward a theory of gentrification a back to the city movement by capital, not people. Journal of the American Planning Association 45(4): 538-548.

Smithsimon G (2008) Dispersing the crowd: bonus plazas and the creation of public space. Urban Affairs Review 43(3): 325-351.

Tang BS (2017) Is the distribution of public open space in Hong Kong equitable, why not?. Landscape and Urban Planning 161: 80-89.

Tang BS and Tang RMH (1999) Development control, planning incentive and urban redevelopment: evaluation of a two-tier plot ratio system in Hong Kong. Land Use Policy 16(1): 33-43.

TD (Transport Department) (2014) Travel Characteristics Survey 2011 Final Report. Transport Department, HKSAR Government, Hong Kong.

TPB (Town Planning Board) (2013) Minutes of 502nd Meeting of the Metro Planning Committee held at 9:00 a.m. on 13.12.2013. Town Planning Board, Hong Kong. 